\title{
KUALITAS AIR BAGI KEHIDUPAN ORGANISME BAGIAN TENGAH DAN HILIR SUNGAI MUSI BERDASARKAN PADA SUMBER POLUTAN
}

\author{
Siswanta Kaban"1), Husnah'1), dan Siti Nurul Aida') \\ 1) Peneliti pada Balai Riset Perikanan Perairan Umum, Mariana-Palembang \\ Teregristrasi I tanggal: 5 Mei 2008; Diterima setelah perbaikan tanggal: 15 Mei 2008; Disetujui terbit tanggal: 25 Juni 2008
}

\begin{abstract}
ABSTRAK
Penelitian ini dilakukan untuk mengetahui kualitas air Sungai Musi tahun 2007 sampai dengan 2008 di bagian tengah dan hilir berdasarkan pada sumber polutan. Empat belas stasiun pengambilan contoh ditetapkan sebagai sumber polutan seperti industri maupun pemukiman penduduk, dan referensi yang jauh dari industri maupun pemukiman yang digunakan sebagai pembanding. Pada setiap stasiun, pengambilan contoh dilakukan 3 kali waktu pengambilan, yaitu bulan April, Juni, dan Januari yang dapat mewakili 3 musim yang berbeda pada tahun tersebut. Beberapa parameter diukur in situ sementara beberapa lain dianalisis di laboratorium dengan standar methods (AWWAWEF, 2005). Dari hasil penelitian didapatkan bahwa industri yang bergerak di bidang pengolahan kelapa sawit dan karet cenderung menurunkan kualitas perairan di Sungai Musi. Kandungan logam berat dalam sedimen di Sungai Musi relatif rendah dengan kandungan $\mathrm{Cr}+6$ dan $\mathrm{Pb}$ yang tertinggi masing-masing 13,481 dan 1,747 $\mu \mathrm{g}$ per g. Curah hujan cenderung menurunkan beberapa parameter fisika dan kimia kualitas perairan. Potensi pencemaran cenderung ditemukan di bagian hilir Sungai Musi, karena sebaran industri dan intensitas pemanfaatan perairan cukup tinggi di bagian sungai tersebut.
\end{abstract}

KATAKUNCl: $\quad$ kualitas air, sumber polutan, Sungai Musi

ABSTRACT: Water quality for organism living on the middle and down stream of Musi River based on the pollution source. By: Siswanta Kaban, Husnah, and Siti Nurul Aida

\begin{abstract}
Study in order to know distribution of pollution source and its effect on water quality of the middle and down stream of Musi River was conducted in April and June 2007 and January 2008. Fourteen sampling sites were selected based on the pollution source and the minimal degradation site (reference sites). Parameters observed were pollution source distribution and water and sediment parameters such as physical and chemical parameters. Water sample was collected at $0.5 \mathrm{~m}$ from water surface by using Kemmerer water sampler while sediment samples were taken by using Ekman grab. Some of the parameters were analyzed in situ while the rest were analyzed in laboratory. Results indicated that oil palm and rubber industries were mostly the pollution source in Musi River. Potential pollution source was mostly found in the middle and down stream of Musi River since most of pollution source and high water utilization found in this area. Water quality parameters except total suspended solid and biochemical oxygen demand, were still in the range that can be tolerated by the aquatic organisms. Rain fall tends to decrease water quality of the river. Concentration of heavy metal such as Chrom $\left(\mathrm{Cr}^{+6}\right)$ and plumbum in the sediment were in still in low concentration with the highest concentration reaching 13.481 and $1.747 \mu \mathrm{g}$ per $g$ respectively.
\end{abstract}

KEYWORDS: $\quad$ water quality, pollutan sourcess, Musi River

\section{PENDAHULUAN}

Sungai Musi adalah suatu sistem yang sangat erat hubungannya dengan aktivitas manusia. Intensitas pemanfaatan Sungai Musi sangat tinggi jika ditinjau dari aspek yang sama di bidang pertanian maupun industri. Bagian hulu sampai dengan tengah Sungai Musi cenderung memanfaatkan pertanian sebagai kegiatan ekonomi masyarakat sehari-hari, sedangkan di tengah sebagian menjadi lahan industri dan bagian hilir didominasi oleh industri dalam skala kecil maupun dalam skala besar. Sebagian besar industri tersebar di pingiran Sungai Musi dan limbah cenderung langsung dialirkan ke Sungai yang sebelumnya telah diolah dengan proses kimia tertentu, akan tetapi limbah kemungkinan dapat menyebabkan degradasi lingkungan. Sumber pencemar sungai dibedakan menjadi sumber domestik (rumah tangga) yaitu dari perkampungan, kota, jalan, pasar, terminal, rumah sakit, serta sumber non domestik yaitu pabrik, industri, pertanian, peternakan, perikanan, dan transportasi yang dapat berbentuk cair maupun dalam padatan (Sastrawijaya, 2000). Pemantauan tingkat pencemaran Sungai Musi telah dilaksanakan oleh Bappedal (1996) melalui kegiatan prokasih menunjukkan bahwa sebagian Sungai Musi telah mengalami degradasi. Hal ini, ditunjukkan dari pengukuran terhadap parameter kualitas air di daerah

Kosrespondensi penulis:

Jl. Beringin No.308, Mariana, PO BOX 1125-Palembang 30763, Telp/Fax: (0711-37194/0711-537205) 
aliran Sungai Musi yang melebihi baku mutu lingkungan seperti kandungan faecal coliform (>2.000/ $100 \mathrm{ml}$ ) dan total suspended solid (>50 mg per I). Pada penelitian ini ditinjau berdasarkan pada kegiatan industri di pinggiran Sungai Musi seperti hal, industri cat, karet, semen, kayu, sawit, minyak, dan mungkin yang lain yang menjadi sumber polutan dalam perairan di Sungai Musi. Di samping itu, juga pemukiman penduduk juga mempunyai andil yang besar dalam pencemaran lingkungan, karena kurang kesadaran masyarakat akibat dari pencemaran lingkungan yang pada umumnya membuang sampah dan limbah organik langsung ke perairan. Berdasarkan pada sumber polutan ini diharapkan dapat diketahui bagaimana degradasi lingkungan dan juga dapat diketahui komposisi serta penyebaran jenis-jenis polutan. Dengan mengelompokkan jenis polutan dan dihubungkan dengan kualitas perairan sehingga diharapkan dapat digunakan sebagai sumber informasi kualitas perairan bagian tengah dan hilir Sungai Musi untuk pemanfaatan pengelolaan air minum, kegiatan pariwisata serta pengelolaan perikanan.

\section{BAHAN DAN METODE}

Survei pengukuran kualitas air dilakukan di bagian tengah dan hilir Sungai Musi berdasarkan pada sumber bahan polutan. Penelitian ini dilakukan pada bulan April sampai dengan Juni, Juni sampai dengan Januari untuk melihat kondisi pada musim hujan dan musin kering. Stasiun pengambilan contoh berdasarkan pada sumber polutan yang dihasilkan, mulai dari daerah perkebunan dan industri serta referensi sebagai pembanding seperti hal industri karet, industri pupuk, industri kayu, industri semen, industri minyak bumi, pemukiman penduduk, dan hutan rawang yang digunakan sebagai referensi (Gambar 1).

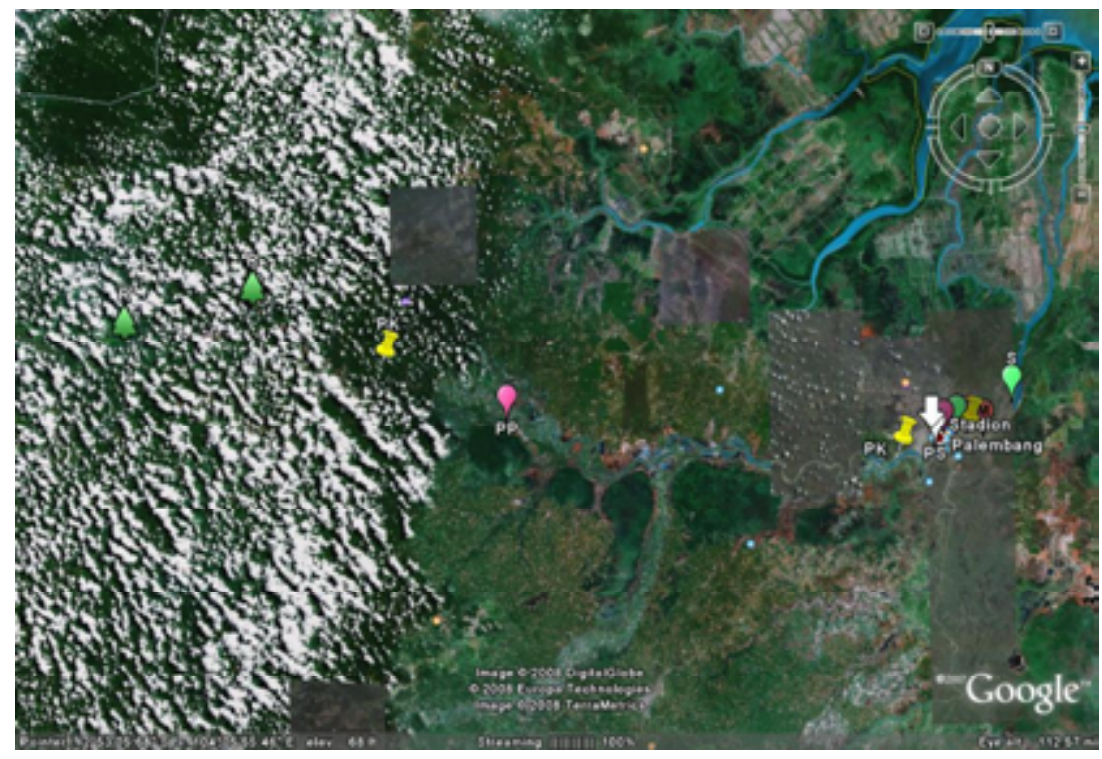

Gambar 1. Peta lokasi pengambilan contoh.

Figure 1. Map of sampling station.

Keterangan/Remarks: $\mathrm{R}=$ referensi; $\mathrm{PK}=$ pabrik karet; $\mathrm{PP}=$ pemukiman penduduk; $P S=$ pabrik semen; $P W=$ pabrik playwood; $\mathrm{PM}=$ pabrik minyak; $\mathrm{P}=$ pabrik pupuk; $\mathrm{S}=$ pabrik sawit

Sumber/Sources: www.google.earth.com

Parameter fisika kimia yang dianalisis meliputi $\mathrm{pH}$, total dissolved solid, total suspended solid, oksigen terlarut (oxygen demand), biochemical oxygen demand, nitrit, nitrat, orthopospat, amoniak, bahan organik (organic matter), chemical oxygen demand, dan sedimen untuk analisis logam berat. Pengambilan contoh air dilakukan dengan menggunakan water sampler dengan jarak $1 \mathrm{~m}$ dari permukaan, sebagian parameter fisika maupun kimia dianalisis secara in situ, dan sebagian untuk contoh air dianalisis di laboratorium kimia Balai Riset Perikanan Perairan Umum menggunakan metode standar method (APHA 2005) (Tabel 1). Pengambilan contoh sedimen dilakukan menggunakan ekman grab, dan ditentukan kandungan logam berat di sedimen seperti $\mathrm{Cr}^{+6}$, plumbum dengan menggunakan atomic absorption spectrofhotometry, di Lembaga IImu Pengetahuan Indonesia-Cibinong di mana untuk logam berat ini hanya dilakukan untuk 2 kali pengukuran. 


\section{Analisis Data}

Data disajikan dalam tabel dan grafik sehingga dapat digambarkan sumber polutan yang sangat berpengaruh terhadap pencemaran sungai dan perubahan musim terhadap kualitas air.

\section{HASIL DAN BAHASAN}

\section{Indikator Pencemar}

\section{Total Suspended Solid}

Hasil pengukuran kandungan total suspended solid di Sungai Musi terlihat paling tinggi di darerah referensi bagian tengah, ini mungkin disebabkan oleh curah hujan yang tinggi sehingga menyebabkan banyak tanah yang terkikis dari pinggiran atau tepian sungai.

Terjadi penurunan kadar total suspended solid, hal ini mungkin disebabkan oleh curah hujan yang cukup tinggi, pelapukan batuan dan pengaruh antropogenik (berupa limbah industri dan domestik) (Gambar 2). Bahan-bahan terlarut pada perairan alami tidak bersifat toksik, akan tetapi jika berlebihan akan meningkatkan nilai kekeruhan yang selanjutnya menghambat penetrasi ke dalam air dan berpengaruh terhadap proses fotosintesis di perairan (Effendi, 2003).

\section{Total Dissolved Solid}

Zat padat yang dapat lolos melalui saringan yang berpori 0,45 $\mu \mathrm{m}$, terlihat pada Gambar 3 bahwa di

Tabel 1. Metode analisis parameter fisika dan kimia contoh air Table 1. The method analysis of water quality characteristics

\begin{tabular}{|c|c|c|c|}
\hline Parameter & Satuan & Metode & Peralatan \\
\hline 1. TSS & $\mathrm{mg} / \mathrm{l}$ & Gravimetri & Gravimetri \\
\hline 2. TDS & $\mathrm{mg} / \mathrm{l}$ & Gravimetri & Gravimetri \\
\hline 3. $\mathrm{DHL}$ & $\mu \mathrm{mhos} / \mathrm{cm}$ & In situ & Condutivity \\
\hline 4. $\mathrm{pH}$ & $\mathrm{pH}$ unit & In situ & pH universal indicator \\
\hline 5. Oksigen terlarut & $\mathrm{mg} / \mathrm{l}$ & In situ, titrimetri metode Winkler & Larutan thiosulfat sebagai titrant \\
\hline $\begin{array}{l}\text { 6. Biologycal Oxygen } \\
\text { Demand }\end{array}$ & $\mathrm{mg} / \mathrm{l}$ & Titrimetric & Larutan thiosulfat sebagai titrant \\
\hline 7. NO3-N & $\mathrm{mg} / \mathrm{l}$ & Spectrofotometric & Spectrofotometer \\
\hline 8. PO4-P & $\mathrm{mg} / \mathrm{l}$ & Spectrofotometric & Spectrofotometer \\
\hline 9. $\mathrm{NO} 2-\mathrm{N}$ & $\mathrm{mg} / \mathrm{l}$ & Spectrofotometric & Spectrofotometer \\
\hline 10. NH3-N & $\mathrm{mg} / \mathrm{l}$ & Spectrofotometric & Spectrophotometer \\
\hline $\begin{array}{l}\text { 11. Chemical oxygen } \\
\text { demand }\end{array}$ & $\mathrm{mg} / \mathrm{l}$ & Titrimetric & Larutan thiosulfat sebagai titrant \\
\hline 12. Bahan organik & $\mathrm{mg} / \mathrm{l}$ & Titrimetric & KMnO4 sebagai titrant \\
\hline 13. Logam berat $\left(\mathrm{Pb}, \mathrm{Cr}^{+6}\right)$ & $\mu g / g$ & Spectrofotometry & $\begin{array}{l}\text { Atomic Absorption } \\
\text { Spectrofotometer }\end{array}$ \\
\hline
\end{tabular}

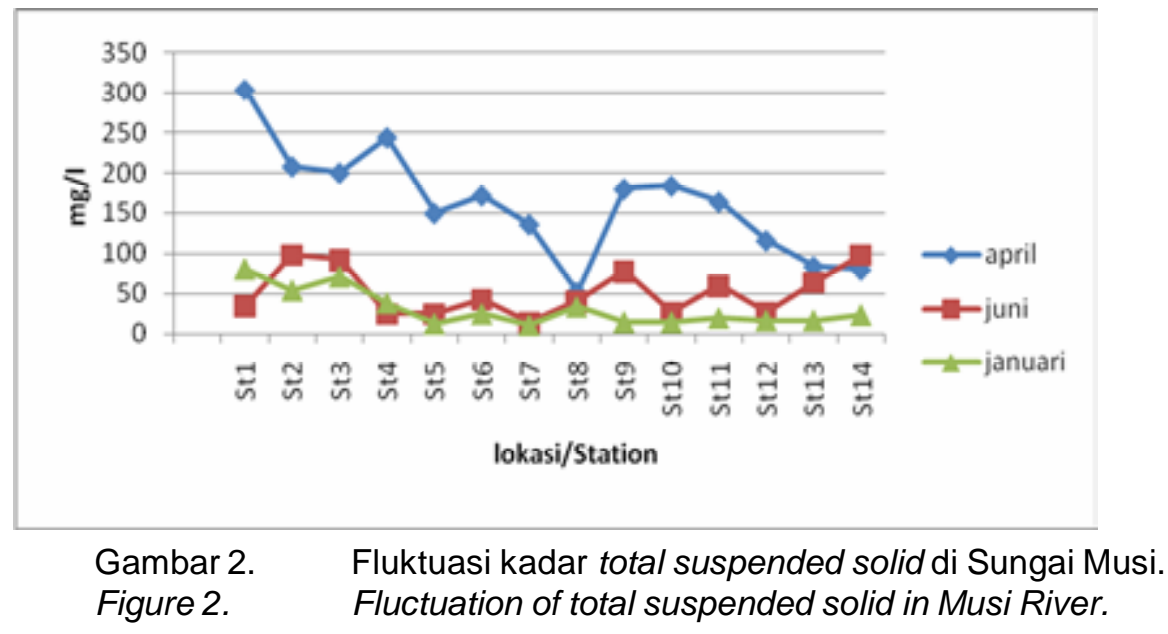


Sungai Musi total dissolved solid tidak terlalu signifikan.

Hanya terlihat bahwa kadar total dissolved solid relatif tinggi di stasiun 10 , hal ini mungkin disebabkan oleh bahan kimia yang digunakan dialirkan ke Sungai Musi. Nilai total dissolved solid juga dipengaruhi oleh pelapukan batuan, limpasan dari tanah dan pengaruh antropogenik (berupa limbah domestik dan industri) (Effendi, 2003).

\section{DHL (Conductivity)}

DHL adalah emampuan suatu larutan untuk menghantarkan arus listrik, jadi di sini dilihat kadar zat terlarut yang mengion di dalam air. DHL cenderung berbanding lurus dengan zat terlarut atau total dissolved solid. Dari grafik total dissolved solid (Gambar 3) dapat disimpulkan bahwa daya hantar listrik yang paling besar berada di daerah pabrik pupuk.

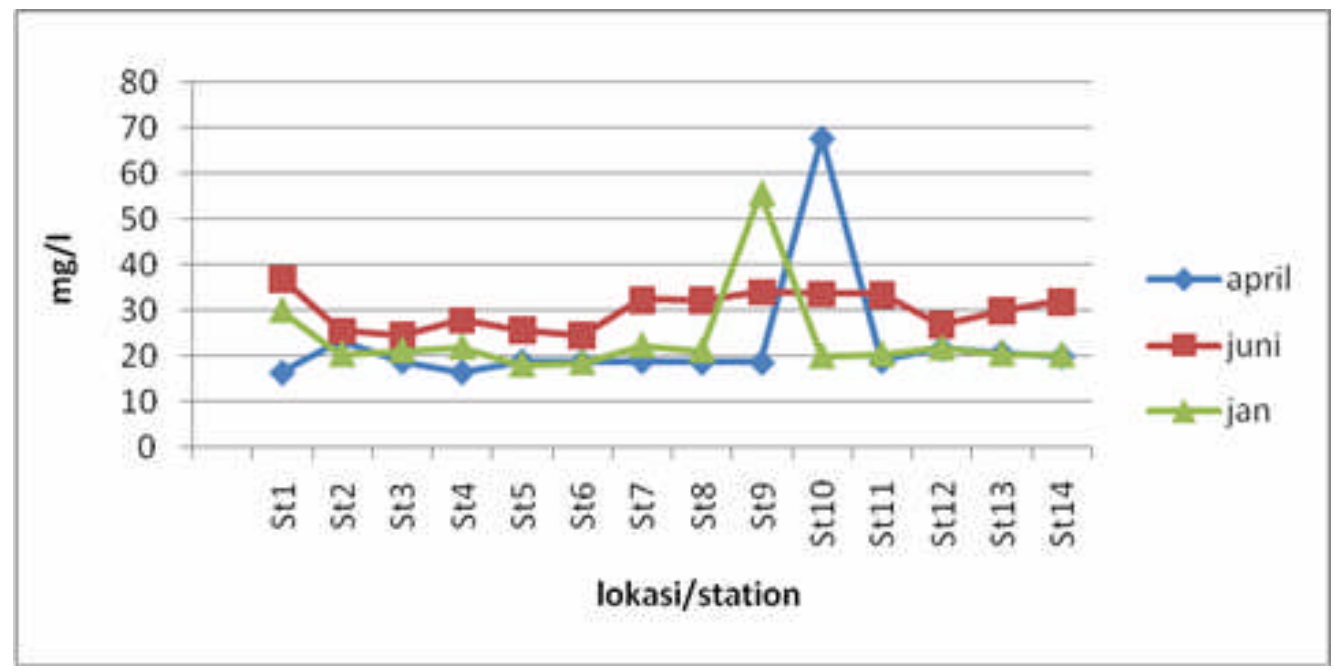

Gambar 3. Fluktuasi kadar total dissolved solid di Sungai Musi.

Figure 3. Fluctuation of total dissolved solid in Musi River.

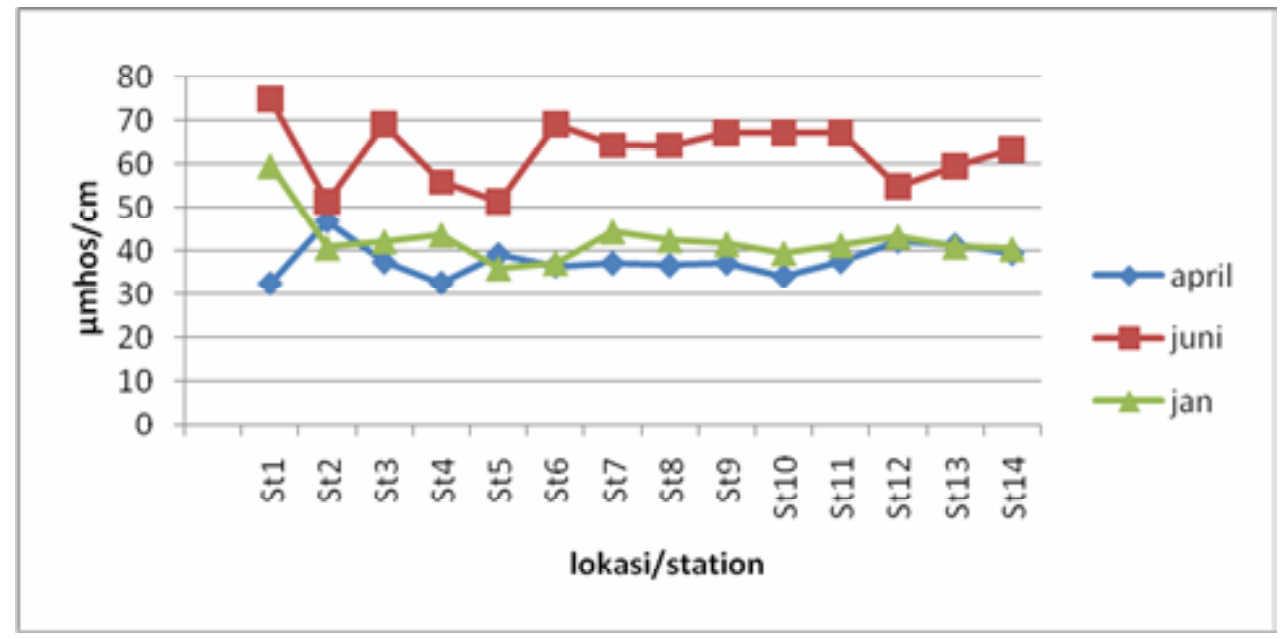

Gambar 4. Fluktuasi kadar DHL di Sungai Musi.

Figure 4. Fluctuation of DHL in Musi River

Nilai daya hantar listrik lebih tinggi di daerah referensi, tapi diambang batas, semakin banyak garam-garam terlarut yang dapat terionisasi, maka akan semakin tinggi nilai DHL (Gambar 4). Boyd (1979) mengatakan bahwa nilai DHL perairan alami sekitar 20 sampai dengan $1.500 \mu$ mhos per $\mathrm{cm}$.

\section{Chemical Oxygen Demand}

Hasil pengukuran chemical oxygen demand pada tiap-tiap stasiun untuk ke-3 series (Gambar 5) menunjukkan kisaran antara 0,5 sampai dengan 15 mg per I, sedangkan baku mutu untuk kepentingan 
perikanan lebih d"20 mg per I, kadar chemical oxygen demand yang paling besar $15 \mathrm{mg}$ per I di stasiun 10 di bulan April, hal ini disebabkan banyak bahan organik yang merupakan buangan limbah industri berupa $\mathrm{CO}$ $(\mathrm{NH} 2)^{2}$ yang kemungkinan tidak dapat diuraikan oleh mikrorganisme ataupun aktivitas rumah tangga yang ada di sekitar perairan berupa detergen. Perairan yang tercemar lebih dari 200 mg per I dan pada limbah industri dapat mencapai 60.000 mg per I (Boyd, 1979). Nilai chemical oxygen demand menggambarkan banyak pencemaran kimiawi organik yang dapat menurunkan kandungan oksigen di perairan sehingga akan menggangu pernafasan biota air.

\section{Bahan Organik (Organic Matter)}

Bahan organik merupakan indikator yang dapat digunakan untuk melihat pencemaran suatu perairan, di sini ditinjau dari industri yang ada di sekitar perairan, ternyata bahwa industri pengolahan kelapa sawit cenderung membuat kadar bahan organik di perairan lebih besar, ini dapat ditunjukkan pada Gambar 6. Peningkatan bahan organik ke bagian hilir, ini disebabkan semakin banyak daerah industri, maupun aktivitas rumah tangga.

\section{Okigen Terlarut (Oxygen Demand)}

Konsentrasi oksigen terlarut merupakan parameter penting untuk mengetahui kualitas perairan dan sebagai petunjuk tentang adanya pencemaran bahan organik (Nybakken, 1982 dalam Adriman, 1995). Perairan air tawar kadar terlarut berkisar antara 15 mg per I pada suhu $0^{\circ} \mathrm{C}$ dan pada suhu $25^{\circ} \mathrm{C}$ kadar oksigen pada perairan umum kurang dari $10 \mathrm{mg}$ per $\mathrm{I}$. Dari hasil penelitian untuk masing-masing stasiun pengamatan menunjukkan kisaran antara 2,2 sampai dengan 6,9 mg per I. Gambar 7 menunjukkan bahwa terjadi penurun kadar oksigen, hal ini disebabkan seiring dengan peningkatan bahan organik dan lebih

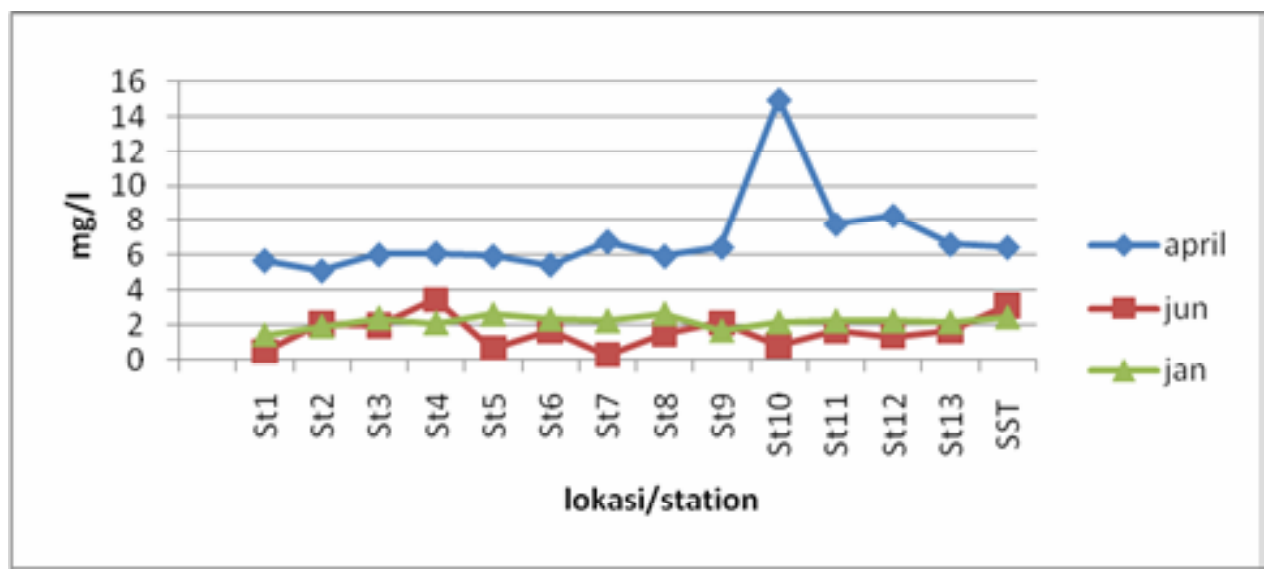

Gambar 5. Fluktuasi kadar chemical oxygen demand di Sungai Musi.

Figure 5. Fluctuation of chemical oxygen demand in Musi River.

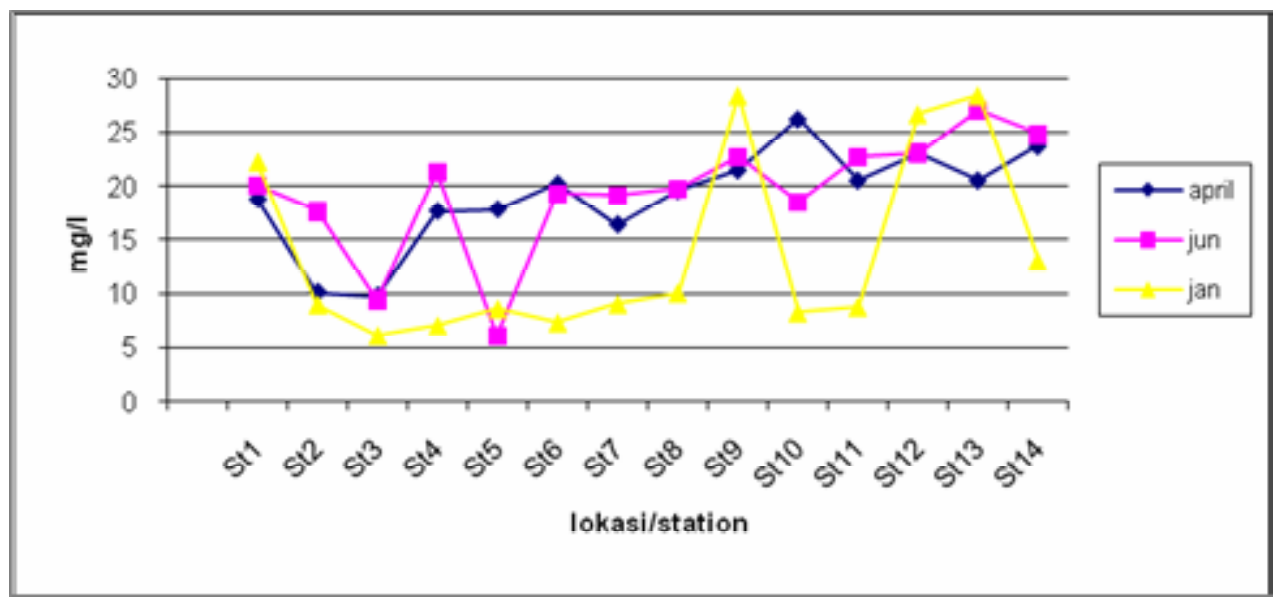

Gambar 6. Fluktuasi kadar bahan organik di Sungai Musi.

Figure 6. Fluctuation of organic matter in Musi River 
derasnya arus di bagian tengah dibandingkan dengan arus di daerah hilir.

\section{Biochemical Oxygen Demand}

Biochemical oxygen demand menunjukkan jumlah oksigen terlarut yang dibutuhkan oleh mikrorganisme hidup untuk menguraikan atau mengoksidasi bahanbahan buangan dalam air. Nilai biochemical oxygen demand perairan dipengaruhi oleh suhu, densitas plankton, keberadaan mikroba serta jenis, dan kandungan bahan organik. Perairan alami memilki nilai biochemical oxygen demand antara 0,5 sampai dengan 7,0 mg per I (Jeffries \& Mills, 1996), dari data yang diperoleh bahwa nilai biochemical oxygen demand yang paling tinggi berada di stasiun 3 yaitu 21,4 mg perl dan juga di stasiun 4 yang merupakan daerah pemukiman penduduk nilai biochemical oxygen demand relatif tinggi, jika ditinjau dari grafik bahwa nilai biochemical oxygen demand relatif tinggi di wilayah industri, ini menunjukkan bahwa buangan industri di pinggiran sungai suatu masalah serius bagi pencemaran Sungai Musi. Karena perairan yang memiliki nilai biochemical oxygen demand lebih dari $10 \mathrm{mg}$ per I dianggap telah mengalami pencemaran.

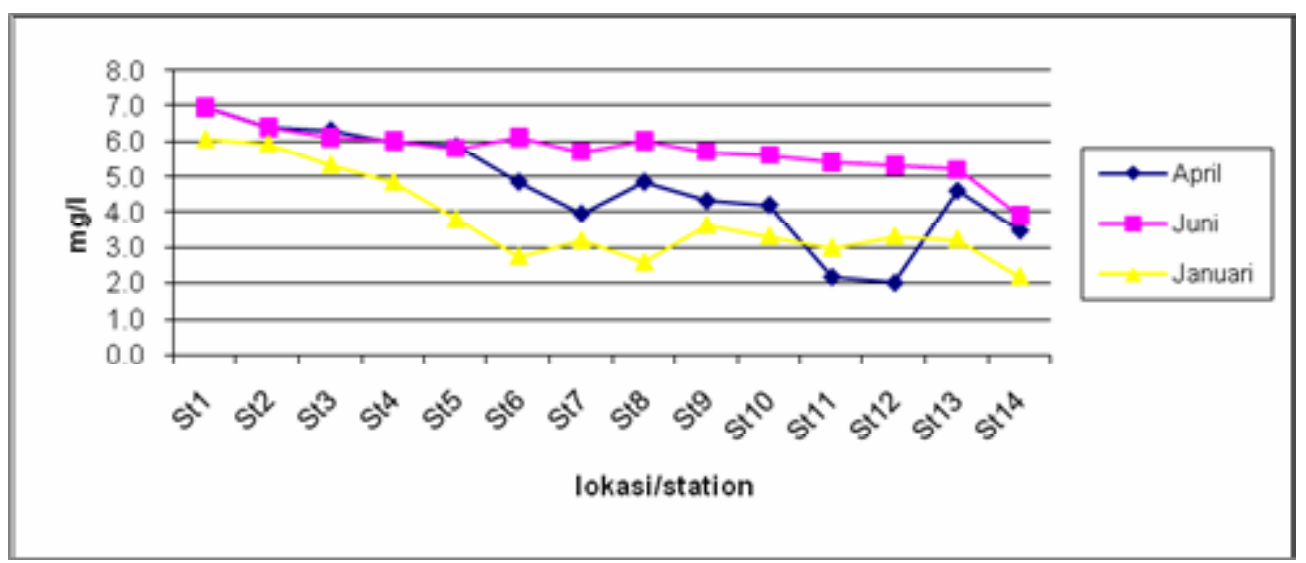

Gambar 7. Fluktuasi kadar oksigen terlarut di Sungai Musi.

Figure 7. Fluctuation of dissolve oxygen in Musi River.

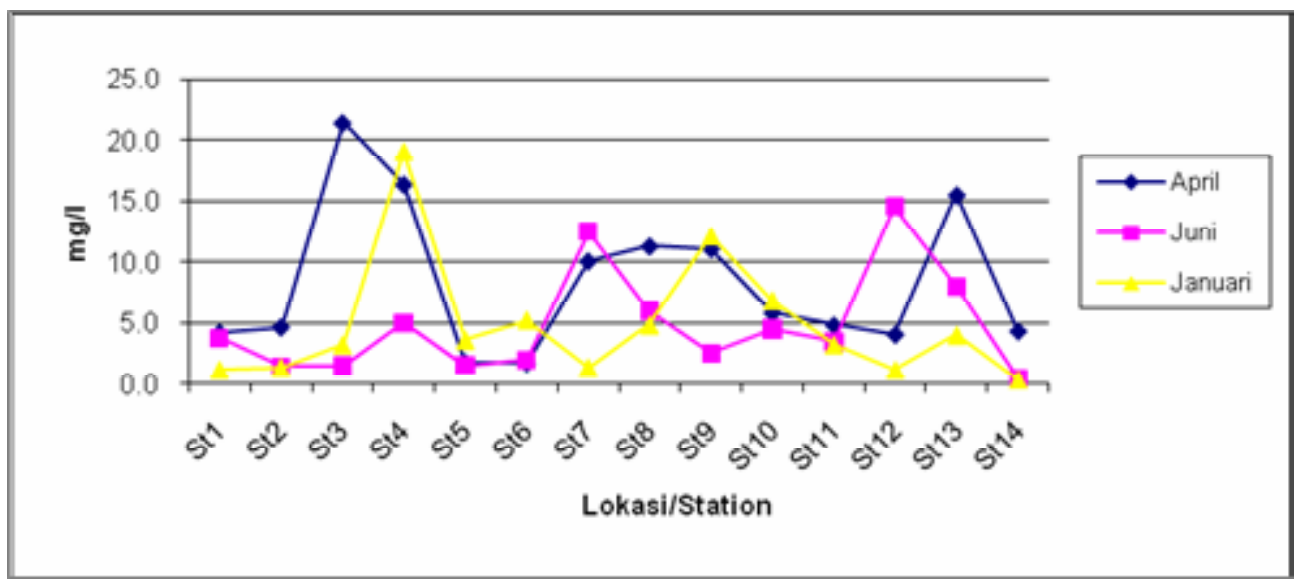

Gambar 8. Fluktuasi kadar biochemical oxygen demand di Sungai Musi. Figure 8. Fluctuation of biochemical oxygen demand in Musi River

\section{Logam Berat (Heavy Metal)}

Logam berat merupakan salah satu unsur kimia yang mempunyai densitas $5 \mathrm{gr} \mathrm{cm}^{-3}$ (Miettinen, 1977), $\mathrm{Pb}$ dan $\mathrm{Cr}^{+6}$ termasuk ke dalam logam berat, apabila masuk ke dalam tubuh organisme akan terakumulasi, sehingga cepat atau lambat akan membahayakan kehidupan organism tersebut (Yatim et al., 1979). Dari hasil penelitian diperoleh (data terlampir) bahwa kandungan logam berat $\mathrm{Cr}^{+6}$ ditemukan tertinggi di stasiun 12 pada musim kemarau 13,481 $\mu \mathrm{g}$ per g, sedangkan untuk logam berat plumbum tertinggi yaitu pada musim kemarau di stasiun $9(1,747 \mu \mathrm{g}$ per g), di mana daerah ini merupakan daerah perindustrian dan aktivitas transportasi menggunakan kendaraan air cukup tinggi. Logam berat dalam sedimen di Sungai Musi dalam keadaan standar jika ditinjau dari kisaran kandungan logam berat dalam sedimen (Tabel 2). 
Tabel 2. Beberapa kisaran logam berat dalam sedimen dan tanah Table2. Range of contain the heavy metal in land and sediment

\begin{tabular}{cccc}
\hline Unsur/Elements & Kisaran/ Range $\mathbf{( m g / k g )}$ & Unsur/Elements & Kisaran/ Range $\mathbf{( m g / k g )}$ \\
\hline $\mathrm{Cd}$ & $0,05-0,22$ & $\mathrm{Fe}$ & $17.000-65.000$ \\
$\mathrm{Cr}$ & $11,0-72,0$ & $\mathrm{~Pb}$ & $5,7-150$ \\
$\mathrm{Cu}$ & $5,1-250$ & $\mathrm{Mn}$ & $460-6.700$ \\
\hline
\end{tabular}

\section{Kandungan Zat Hara (Amoniak, Fosfat, Nitrat, atau Nitrit)}

Kandungan zat hara, amoniak, fosfat, nitrat, atau nitrit tidak terlalu signifikan terhadap perubahan musim, kandungan fosfat antara 0,0075 sampai dengan $0,84 \mathrm{mg}$ per I, sedangkan kandungan amoniak 0,01 sampai dengan $0,336 \mathrm{mg}$ per I, kandungan nitrat 0,019 sampai dengan $0,366 \mathrm{mg}$ per I dan kandungan nitrit 0,00056 sampai dengan $0,48 \mathrm{mg}$ per I (Tabel 10 terlampir) sehingga dari data tersebut bahwa baik digunakan untuk kepentingan perikanan dan dari kandungan zat hara tersebut tidak terlalu fluktuatif, hanya bulan April kandungan amoniak di daerah pusri cukup tinggi 0,336 mg per I ini sehingga kemungkinan menyebabkan kematian biota perairan. Kandungan ammonia bebas di perairan melebihi dari 0,2 $\mathrm{mg}$ per I dapat menyebabkan kematian beberapa jenis ikan (Sawyer \& Mc Carty dalam Effendi, 2000).

\section{KESIMPULAN}

Kualitas perairan Sungai Musi relatif baik kecuali untuk kandungan zat padat terlarut total suspended solid dan biochemical oxygen demand masing-masing 304 dan 21,4 mg per I pada musim hujan. Potensi sumber pencemar berada di bagian tengah hilir Sungai Musi adalah industri yang bergerak di bidang pengolahan sawit dan karet. Logam berat di sedimen jika ditinjau berdasarkan pada sumber polutan dalam keadaan normal. Sungai Musi baik digunakan untuk pengelolaan air minum, pariwisata, dan pengelolaan perikanan.

\section{PERSANTUNAN}

Kegiatan dari hasil riset penentuan tingkat degradasi dan variasi metode penentuan degradasi lingkungan di perairan Sungai Musi, T. A. 2007, di Balai Riset Perikanan Perairan Umum-Mariana, Palembang. Ucapan terima kasih pada Proyek Fish Integrated Benthic Index serta anggota tim riset yang sangat membantu dalam pelaksanaan dan pengumpulan data ini.

\section{DAFTAR PUSTAKA}

Adriman. 1995. The quality of Dumai coastal water based on physical chemistry characteristics. Biological Conservation. Vol.97. Elsiever Science Ltd. P.239-249.

AWWA-WEF. 2005. Standar methods for examination of water and wastewater. $21^{\text {st }}$ edition. American Public Health Association 800 I Street N. W. Washington D. C. p. 4.-108-4-149.

Andrew, D. E., S. C. Lenore, W. R. Eugene, and E. G. Arnold. 2005. Standar methods for examination of water and wastewater (APHA). $21^{\text {st }}$ Edition. American Public Health Associattion 800 I Steet. NW Washington DC. p.4-108-4-149.

Boyd, C. E. 1979. Water quality in warmwater fishpond. Auburn University. Department of Fisheries and Alied Aquaculture. First Edition. Alabama. USA. 359 pp.

Effendi, H. 2003. Telaah kualitas air: Bagi pengelolaan sumber daya dan lingkungan perairan. Penerbit Kanisius. Yogyakarta. $245 \mathrm{hlm}$.

Jeffries, M. \& D. Mills. 1990. Freshwater ecology principles and application. Bathoren London and New York. 285 hlm.

Meittenn, J. K. 1977. In organic trace elements as water pollutiontheir implication to health of water and aquatic biota. Water Quality Procedding. Academic Press New York. p.133-136.

Nybakken, J. W. 1988. Biologi laut suatu pendekatan ekologis. PT. Gramedia. Jakarta. $333 \mathrm{hlm}$.

Sastrawijaya. 2000. Pencemaran lingkungan. Cetakan Ke-2. Penerbit PT Rineka Cipta. Jakarta. $273 \mathrm{hlm}$.

Yatim, S., S. Surtipanti, S. Syamsul, \& E. Lubis. 1979. The heavy metals distribution in sea water of Jakarta Bay. Majalah Batan. No.12. p.1-19.

http://earth.google.com/download-earth.html. diakses tanggal 1 Januari 2008. 


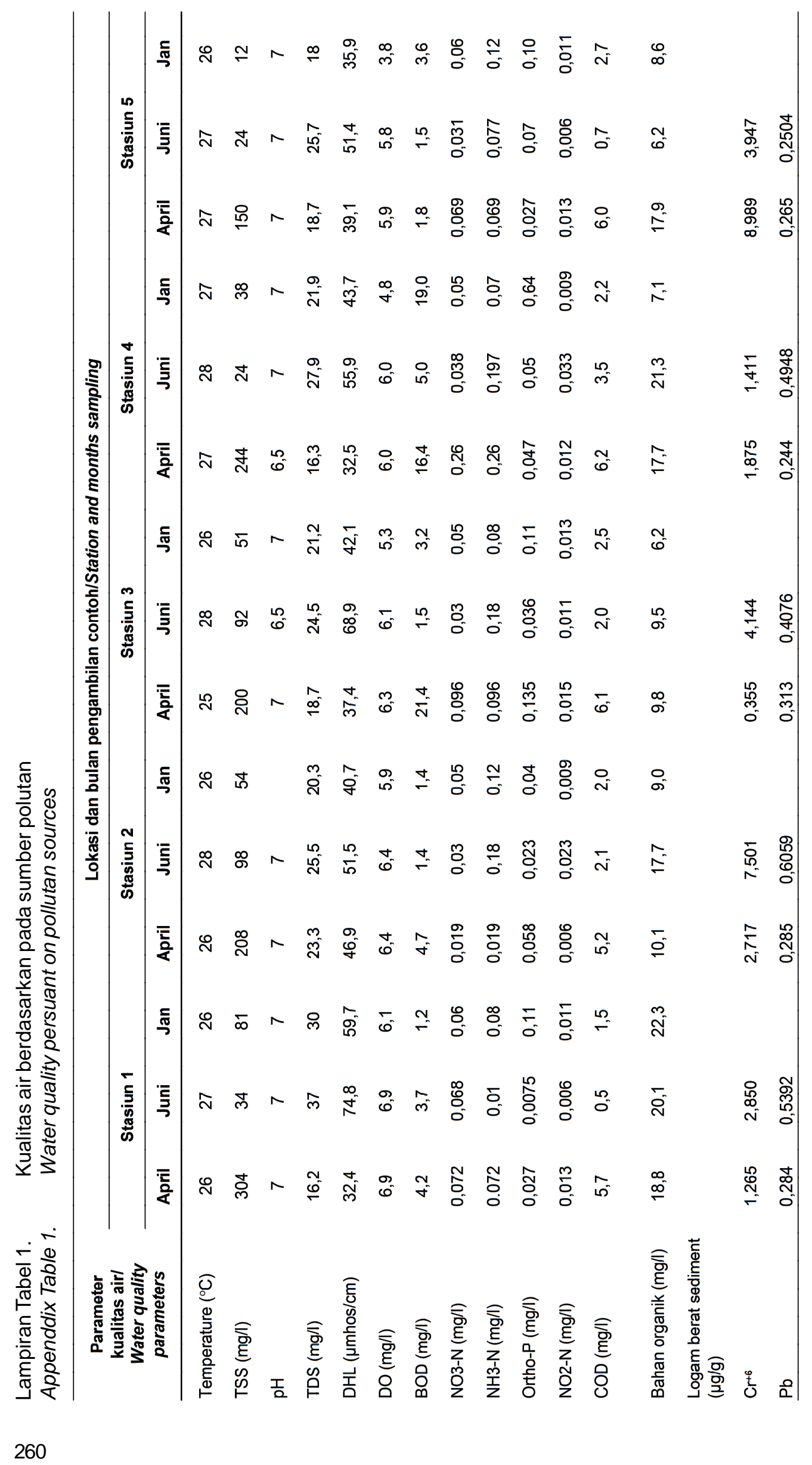






